\title{
安政度内裏遷幸と都市空間 \\ THE EMPEROR'S PARADE TO IMPERIAL PALACE AT ANSEI PERIOD \\ AND THE URBAN SPACE
}

\author{
岸泰子*
}

\section{Yasuko KISHI}

\begin{abstract}
The parade started at the temporary imperial palace of Katsura and went through the streets where many powerful merchants lived to the Imperial palace at Ansei period. In deciding the course of this parade, Emperor's view "Omikoshi” was important. At the area along this parade course, the environment suitable for "Omikoshi" was created. This parade was carried out to show off the authority of Emperor and the imperial court. On the other, the towns and merchants along this parade course took a lot of doing. However, they were utilizing this parade to build up their social position to invite the customers to the sightseeing.
\end{abstract}

Keywords : Emperor's parade, imperial palace at Ansei period, Emperor's view, town, urban space 遷幸，安政度内裏，御見越，町，都市空間

\section{はじめに}

近世の天皇について、藤田覚氏は次のように解説する11) 江戸時代の天皇は、禁裏御所から外一出かける行幸がほとんど なかった。(中略) 江戸時代前期の朝軦行幸では、わずかな距離 の沿道に栈敷が設けられ、また一七九○(寛政二)年に、火災で 焼け再建された新造禁裏御所一避難先の聖護院仮御所から戻る 光格天皇の行列(遷幸とよび行幸ではない)では、沿道の町屋な どに大勢の見物人が出ている。しかし、鳳替は見えても天皇の 姿は見えない。存在はするがその姿は見えない、しかしいった ん外にでると多数の見物人がでる、それが江戸時代の天皇だっ た。

天皇の内裏への遷幸は安政 2 年 (1854) にも行われた（以下、安政度 内裏遷幸とする)。後述のように、築地之内にあった仮御所(桂皇居) にいた天皇は、今出川御門を出て、室町通、三条通、堺町通を通っ て新造内裏に還る。これを見物するために、寛政度と同様、多くの 人々が集まった ${ }^{2)}$

この内裏遷幸に関しては、建築史学の分野において、寛政度およ び安政度の沿道のしつらえや町家の特徴に着目した研究の蓄積があ る ${ }^{3)}$ 。だが、これらの研究は遷幸の沿道、町家や築地之内という限 定された地区の景観復元に留まっており、都市の祝祭ともいえる遷 幸の道筋 (経路)の決定の背景や町家の使い方などは明らかにされて いない。

一方、近年、立命館大学グローバル C O E プログラムの報告書 ${ }^{4)}$
(以下、『立命館大学安政度内裏造営報告書』) が発行された。この報告 書には、安政度内裏造営・遷幸時に京都所司代をつとめた脇坂安宅 の日記である『脇坂安宅日記鈔』(宮内庁書陵部所蔵)や『伝奏口上 留』(京都府立総合資料館所蔵)などの史料翻刻と、安政度内裏造営・ 遷幸の経緯や献金に応じた京都町人の動向に関寸る論考が所収され る。安政度内裏造営・遷幸に関して最も端的にまとめられた最新の 研究成果である。ただし、遷幸実施の背景や空間の特性までは明ら かにされていない。よって、遷幸の空間の特性や実施の背景などを より総合的に明らかにすることで、祝祭空間となる近世都市京都の 位置づけをより明確にしていく必要があると考える5)。

以上の研究状況を踏まえて、本稿は、安政度内裏遷幸に着目し、 その実施の背景や空間の特性をより総合的に検討した上で、遷幸を 実施する朝廷側とそれを見物する町側の対応や意図を明らかにする。

\section{1 安政度内裏造営と遷幸の概要}

安政度内裏遷幸の特徴を明らかにする前に、先行研究をもとに安 政度内裏造営の概要をまとめておきたい ${ }^{6)}$ 。

嘉永 6 年(1853) 4 月、女院御所から出た大火は禁裏御所(内裏)や 仙洞御所、そしてその西方一帯の町に拡がった。孝明天皇は、下鴨 神社に一旦避難した後、聖護院に仮御所を置く。その数日後には、 類焼を逃れた桂宮の屋敷に遷幸し、そこに仮御所を置いた。桂宮の 屋敷は、築地之内と呼ばれる内裏を中心とした九門に囲まれた区域 内の北端に位置する。天明の大火後の仮御所が聖護院であったこと

\footnotetext{
* 九州大学大学院芸術工学研究院 准教授・博士 (工学)

Assoc. Prof., Faculty of Design, Kyushu University, Dr. Eng.
} 
を考えると、内裏に近接するという立地に特徵があるといえる。

内裏造営は速やかに始まり、安政 2 年 (1854)の秋には完成し、朝 廷側に引き渡される。そして、同年 11 月 23 日、内裹遷幸と内侍所 渡御が行われた。

\section{2 遷幸の空間の特性}

\section{2-1 遷幸の道筋の決定}

次に、安政度内裹遷幸実施の経緯とその空間の特性を整理・分析 してみたい市。

遷幸の内慮が朝廷側から示されたのは、安政 2 年 (1854) 4 月 29 日である ${ }^{8)}$ 。京都所司代の脇坂安宅宛に武家伝奏より書付が届き、 孝明天皇が当年冬中の遷幸を希望している旨が伝えられる。さらに、 5 月 11 日には、関白鷹司政通から脇坂宛に遷幸に関寸る諸向きへの 配慮が内々に示される。ここでいう配慮とは、時節を鑑みて「手数」 や「市中迷惑」をかけないようにするというものである ${ }^{9)}$ これをを うけて道筋の取調が行われ、同月 26 日にその結果が示される。ここ で、その記述のなかから、本遷幸の空間的特徵を示寸部分を抜粋し てみたい。

【史料 1 】『脇坂安宅日記鈔』安政 2 年 5 月 26 日条 (以下、史料 中の下線・丸数字は筆者による)

禁裡 御所向御造畢之上、新 内裹江 遷幸之節、御道筋之儀 為取調候処、(中略)、们御道筋之義寺町通者片側寺院多二而、表 側高塀之向多御見越之程茂難計、(中略)、寬政度二茂寺町通 之義二付、別紙之通り町奉行先役菅沼下野守申聞候書留相見、 御見越之向者目隠等為致候儀二而、場広之儀寺院之向迷惑可致 哉茂難計候付相省、別紙絵図面内之 御道筋二有之候得者、何 れ相成候共先建家取払二不及、辻小路曲角或者首長庇先聊ツ、 切縮申付候迄二而、乍聊此分相応之御手当被下、其余町々木戸 門并番部屋等取除、且盛砂、竹矢来、溝蓋、目隠板囲等者先例 於町分申付、御入用二不相立、夫々町分二而諸雑費相掛り候事 二而、(2)鳥丸通中立売より丸太町迄之間東側者、多分宮方、堂上 方等之構二而、御車より御見越之程茂難計候付、其向々二而差 支之筋無之候八、同通り者木戸門無之木戸柱計二而、番部屋 等茂無数聊之雑費二而相済候、室町通二而中立売より出水北側 迄之間并烏丸通中立売上儿辺焼場跡未家稀二而、多分板囲而已 之場所二有之候、

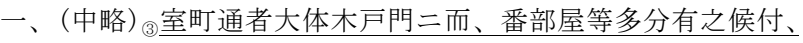
雑費茂相増候儀二候得共、是等者各別之銀高二茂無之、中二者 迷惑いたし侯町柄無之共難申候得共、何れ茂 遷幸之儀者不容 易候処、御通行之御道筋二相成候八、、雑費等二も不拘難 有存、各別迷惑いたし候程之義者有之間敷、(略)

まず、下線部(1)では、寺町通を遷幸道筋とすることへの懸念が記 される。ここで理由として挙がるのが、「御見越」である。寺院が連 なる寺町通を遷幸が通行した場合、高塀が多く、「御見越」が計りが たいという。

加えて、寺町通については、寛政度内裏遷幸時の評価も記される が、下線部(1)で示される寛政度の書留については、次のものが該当 すると考えられる。

【史料 2 『遷幸御用留』(内閣文庫所蔵)

戌六月二日
寺町通御道筋之儀二付申上候書付

\section{菅沼下野守}

禁裏

遷幸御道筋仮

皇居東六門代より岡崎村廣道南江三条通西江寺町通北江武家町 口御門より

入御相成候積御道筋絵図壱枚入御覧候、然ル処寺町通之儀者片 側寺院多二而高塀取建候而茂御見越之御程合茂難斗、其上武家 町口御門之儀者御門明幅狭御車入兼申候、右御門一昨春出火之 節残焼損所有之、此節御修復取掛罷在候間、弥武家町口御門二 相成候得者、当時御修復出来之上、

遷幸之節者御門左右柱切払不申候而者、御車道二相成不申候、 左候而者右御門二重之御修復二相成申候二付、此段申上置候、 以上

$$
\text { 六月二日＼cjkstart菅沼下野守 }
$$

寛政度内裏遷幸は、寛政 2 年 (1790) 年 11 月 22 日に行われた。光格 天皇は仮御所の聖護院から、三条通を西へ、堺町通を北へと進み、 新造内裏に遷幸した ${ }^{10)}$ 。この計画段階において寺町通の「御見越」 の「程合」の難しさや武家町口の門、つまり武家側が管理する寺町 御門の通行が問題となっていたことがわかる。

なお、天皇の内裏遷幸のために修復が終了した寺町御門の柱を切 り払わなければならない事態に対して、武家側が難色を示している。 武家側には遷幸という儀礼が朝廷側のものであるという認識があり、 過大な負担への忌避感があったと考えられる。

では、なぜ、このような問題点が寛政度に提示されていたにもか かわらず、安政度も寺町通の通行が検討されたのであろうか。それ を明確に示す史料はないが、寺町通が近世の朝儀で使用されていた ことは注目に值しよう。その一例が、天皇の葬列(葬送)である。18 世紀中葉まで、崩御した天皇や女院は御車に載せられ、各御所から

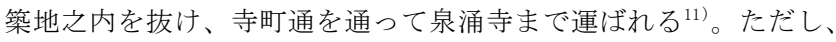
安永 8 年 (1779) の後桃園天皇の葬列は、南門通を西へ、烏丸通を南 へ、三条通を東へ、さらに寺町通を南へ進み、泉涌寺に向かった ${ }^{12)}$ 。 その後の天皇・女院の葬列も、築地之内を出た後は堺町通、烏丸通、 もしくは室町通を南下し、三条通を東行し、寺町通を南下した後、 五条通を通つて泉涌寺に至る ${ }^{13)}$ 。すなわち、寛政度ならびに安政度 遷幸の経路決定に際しては、他の朝儀と同様に先例が参照される過 程で、まず旧例として安永度以前の天皇葬列で使用された寺町通の 通行が検討され、続けて【史料 1 】下線部(2)以下のように安永 8 年 の天皇葬送度以降に使用されていた烏丸通や室町通の通行が検討さ れたのであろう ${ }^{14)}$ 。なお、この「御見越」の内容については、2-3 にて詳述する。

そして、【史料 1】下線部(2)以下では、寺町通以外の具体的な道筋 として、烏丸通等の通行の問題等が検討される。烏丸通に関しては、 中立売通から丸太町の間の間は堂上方などの屋敷が多く、木戸門も 少ないため、その撤去の雑費が少なくて済むと評価する。一方で、 室町通の中立売通から出水通の間は大火で多くの町家が類焼してい たために板囲が必要とする。ただし、下線部(3)では、室町通は、木 戸門や番部屋が多く、撤去のための雑費が増えたことを迷惑と思う かもしれないが、雑費の支出よりも遷幸を「有難」いと捉えて格別 の迷惑ではないとする町も多いと評価している ${ }^{15)}$ このような沿道 
の町の評価のなかで「有難」に言及する記録は寛政度内裏遷幸時に は確認できない。これは、安政度内裏遷幸の特徵といえよう。

結局、遷幸は、図 1 のとおり決定される。桂皇居の西門から出た 鳳輦は、今出川御門から築地之内の外一出た後、今出川通を西へ、 室町通を南へ、三条通を東へ、堺町通を北へ行き、堺町御門を通過 し、仙洞御所の西を通り、南門(建礼門)、承明門から内裏に還る ${ }^{16)}$ 。

\section{2-2 沿道の整備}

遷幸の道筋決定後の安政 2 年 10 月 14 日、奉行所立合のもとで実 地の見分が行われた。『職修日記』(宮内庁書陵部所蔵)や『遷幸御用 留』(内閣文庫所蔵)に記される結果をまとめたものが、表 1 である。 通路幅拡張のための高塀などの後退や町家の庇の取払が必要とされ た箇所と御手当銀の額が判明する ${ }^{17)}$ 。

また、沿道の町にはさらなる対応が求められた。ここで、京都市 歴史資料館所蔵の『蛸薬師町文書』から、その具体的な内容を確認 してみたい。

蛸薬師町は室町通を挟む両側町で、北側を二条通、南側を押小路 通に囲まれる。近世には三井八郎右衛門のほか、淀藩呉服所伊勢屋 や播州藩只服所桔梗屋、長崎系割賦商人らが居住した町である ${ }^{18)}$ 。

安政 2 年 10 月 15 日、西御役所から道筋にあたる同町に御請書が 届けられる ${ }^{199}$ 。

【史料 3 】「新内裏遷幸道筋につき蛸薬師町諸事要用録」（『蛸 薬師町文書』)安政 2 年 10 月 15 日条

\section{御請書}

一、蒔砂 巾武間半 厚壱寸

一、竹矢来 辻占弐間入込壱尔所 町堺際二而壱ケ所

但し丈夫成門有之処者竹矢来一个所可仕旨

一、御見込町々家表側辻 5 三間見世入込之分取払

一、町家表両側見世并孫庇駒寄せ取払

一、町家表御札箱庇之上看板并雨覆屋根堅樋等取払

一、二階空塞キ難取払表格子并むしこ $\nsim$ 切可申候

一、町々有之車除石取除

一、町家表両側溝ふた并伏樋石橋等丈夫二取繥不陸石高之処御 道造可仕候

一、町家表両側二出有之候材木古木古板竹類取払

一、同表側張紙落書類取払

一、同表側壁并土蔵損

所之分取繥家居透間之 処囲ひ可申事

一、石仏辻堂髪結床番 部屋木戸門階子懸芥溜 等取払

一、都而表通御目障無 之様仕御見越二相成場 所八高辛式間之目隠可 仕候

一、屋根二有之候火之 見水溜其外風印等取払 木戸門や辻堂の撤去や蒔砂 や竹矢来などの設置のほか、 各町家の庇や看板などの撤

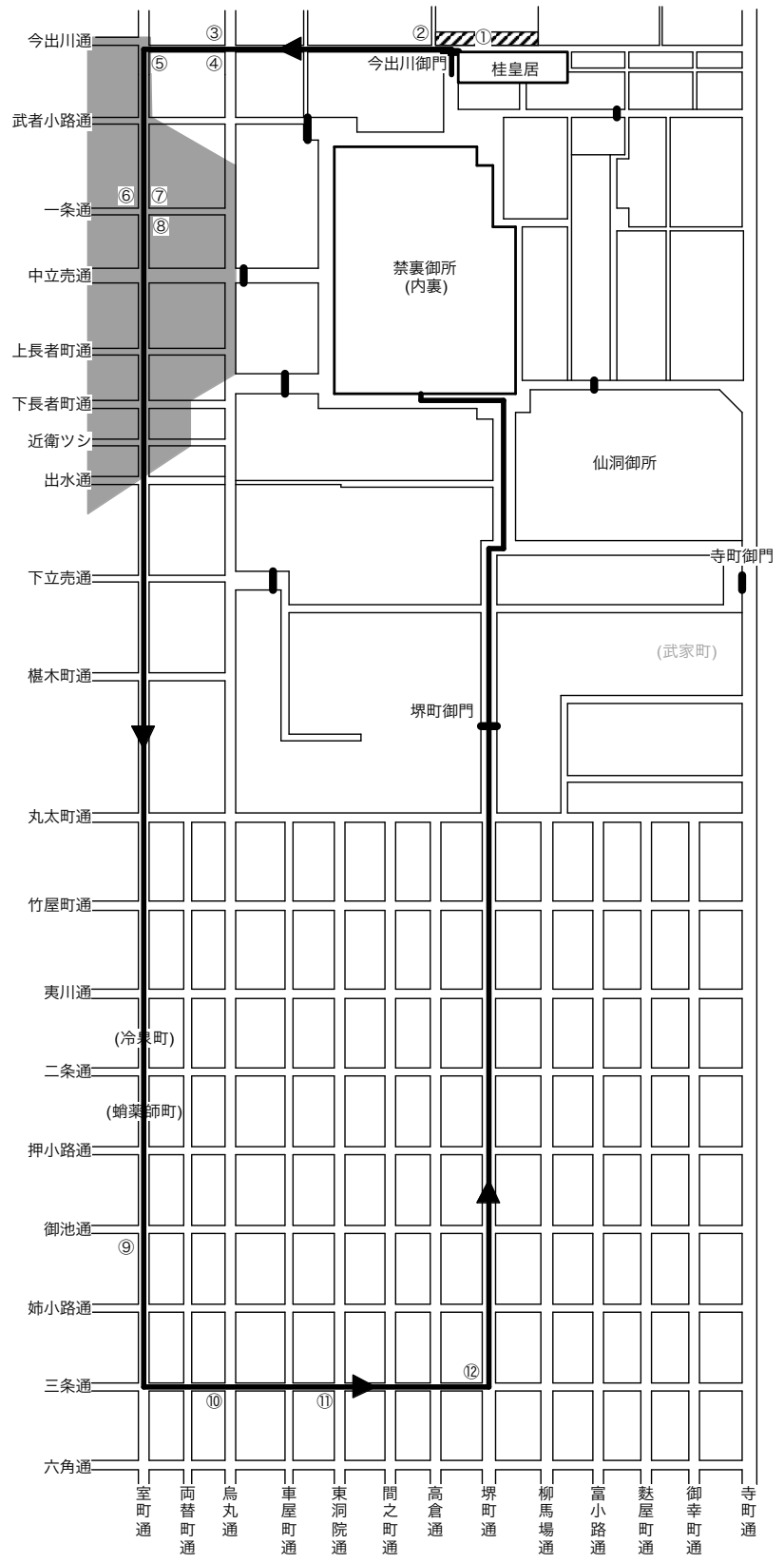

図 1 安政度内裏遷幸道筋

(網掛けの範囲は、嘉永 7 年の火炎で延焼した町の範囲(築地之外の範囲 のみ表示)。丸妿み数字は表 1 と対応。

表 1 安政度内裏遷幸実地検分結果一覧

\begin{tabular}{|c|c|c|c|c|c|c|c|}
\hline 図 1 番号 & 場所 & 土地建物名 & 箇所 & 対応 & 御手当銀額 & 典拠 (※) & 備考 \\
\hline (1) & 伏見宮邸 & & 高塀三問 & 引入 & & 『賳修日記』 & \\
\hline (2) & 今出川通相国寺門前通北西 & 御附武家組屋敷 & 北一間 $\quad$ 西一間半 & 取払 & & 『職修日記』 & \\
\hline (3) & 今出川通烏丸西入町北側 & 町家 & 庇不残 & 取払 & 719 多 3 分 5 厘 & 『遷幸御用留』 & \\
\hline (4) & 今出川通烏丸西入町南側 & 町家 & 庇不残 & 取払 & 574 多 6 分 9 厘 & 『遷幸御用留』 & \\
\hline (5) & 今出川室町東南角 & 若狭屋喜兵衛建家 & \begin{tabular}{|ll} 
一間五分 & 庇 \\
三間五分 & 出格子
\end{tabular} & 取払 & 67 多 9 分 5 厘 & 『遷幸御用留』 & 『職修日記』では東へ 1 問南へ 1 問取払 \\
\hline (6) & 一条室町北西角 & 丹波屋茂兵衛建家 & $\begin{array}{l}\text { 桁行一間半 梁行一間 } \\
\text { (建坪一坪五分) }\end{array}$ & 取払 & $\begin{array}{l}72 \text { 多 } 8 \text { 分 } 1 \text { 厘 } \\
(1 \text { 坪あたり } 48 \text { 多 } 5 \text { 分 } 4 \text { 厘 })\end{array}$ & 『遷幸御用留』 & \\
\hline (7) & 一条室町上ル東側 & (板囲) & 一問余構内人 & 引入 & & 『㖪修日記』 & \\
\hline (8) & 一条室町東南角 & 町用人安兵衛建家 & \begin{tabular}{|l} 
标行二問 梁行一間 \\
(建坪二坪)
\end{tabular} & 取払 & $\begin{array}{l}97 \text { 多 } 8 \text { 厘 } \\
(1 \text { 坪あたり } 48 \text { 多 } 5 \text { 分 } 4 \text { 厘 })\end{array}$ & 『遷幸御用留』 & \\
\hline (9) & 室町御池南西角 & 松屋伊兵衛 & \begin{tabular}{|l|l|l|l|l} 
庇 一問三分 & 六分一厘 \\
出格子一箇所
\end{tabular} & 取払 & 26 多 4 分 5 厘 & 『遷幸御用留』 & 『職修日記』では庇 1 問取払 \\
\hline (10) & 三条烏丸南西角 & 日野屋直七 & \begin{tabular}{|l|} 
庇 五分 七分七厘 \\
(坪三分八厘)
\end{tabular} & 取払 & 9 多 2 分 2 厘 & 『遷幸御用留』 & 『職修日記」では町中物入取払 \\
\hline (11) & 三条東洞院南西角 & 松屋次兵衛 & $\begin{array}{l}\text { 庇 二問 七分七厘 } \\
(\text { (坪一坪五分四厘 })\end{array}$ & 取払 & 37 多 3 分 7 厘 & 『遷幸御用留』 & 『職修日記』では西へ 1 問南へ 1 問取払 \\
\hline (12) & 三条堺町北西角 & 近江屋松之助建家 & $\begin{array}{l}\text { 一間半 一問 } \\
\text { (建坪一坪五分) }\end{array}$ & 取払 & $\begin{array}{l}72 \text { 多 } 8 \text { 分 } 1 \text { 厘 } \\
(1 \text { 坪あたり } 48 \text { 多 } 5 \text { 分 } 4 \text { 厘 })\end{array}$ & 『遷幸御用留』 & 『職修日記』では北へ 1 問西問半取払 \\
\hline
\end{tabular}


去や二階空や虫子空の締切などの景観の整備が重点的に指示されて いる。これらは通路幅の拡張と遷幸空間の荘厳、さらに見物の規制 を目的としたものであり、先行研究で指摘される天皇や上皇の通行 時の対応と共通する部分も多い20)。

ただし、火災後の遷幸においては、【史料 3 】に記されるように、 壁や土蔵の破損箇所や家の隙間への囲いや、「御目障」がないように 「御見越」になる場所への目隠し、などが必要とされている点は注 目しておきたい。

特に、火災発生から 1 年半弱では、室町通の出水通以北の町では、 町家が建ち並ぶ状況にまで至っていなかったのであろう。遷幸御用 留』には、遷幸沿道で「取葺屋根」や「板囲」が設置された箇所が 示されている。そのなかかから被災した一条通と中立売通間の様相 を図 2 に示す。この地区では沿道の面積の約 7 割に高さ 2 間の「取 莫屋根」が設置されたことがわかる。この「取莫屋根」の内容は示 されていないが、図 2 にはすでに家が建っている箇所に別記がある 上に、『日本国語大辞典』(小学館) によれば「取莫屋根」とは粗末 で仮設的な屋根を意味することから、ここでは「取葺屋根」を目隠 しとなるような高さ 2 間の粗末な屋根の仮設的な構築物であったと 判断しておきたい21)。

すなわち、内裏一の遷幸時には、葬列や行幸などの先例に準じて、

しつらい、荘厳、さらに通路幅の拡張のための対応がなされるだけ でなく、不都合な箇所を隠し、さらに延焼した地区を仮設等で補っ た景観が整備されていたことになる。

\section{2-3「御見越」と遷幸の空間}

では、経路決定や町並の整備の理由として度々取り上げられる「御 見越」とは、何を指すのであろうか。

【史料 $1 】 の$ 記述等を総合的に判断して、ここでは、天皇の上覧 を指すと考える。ただし、その上覽の内容については、【史料 3 】に

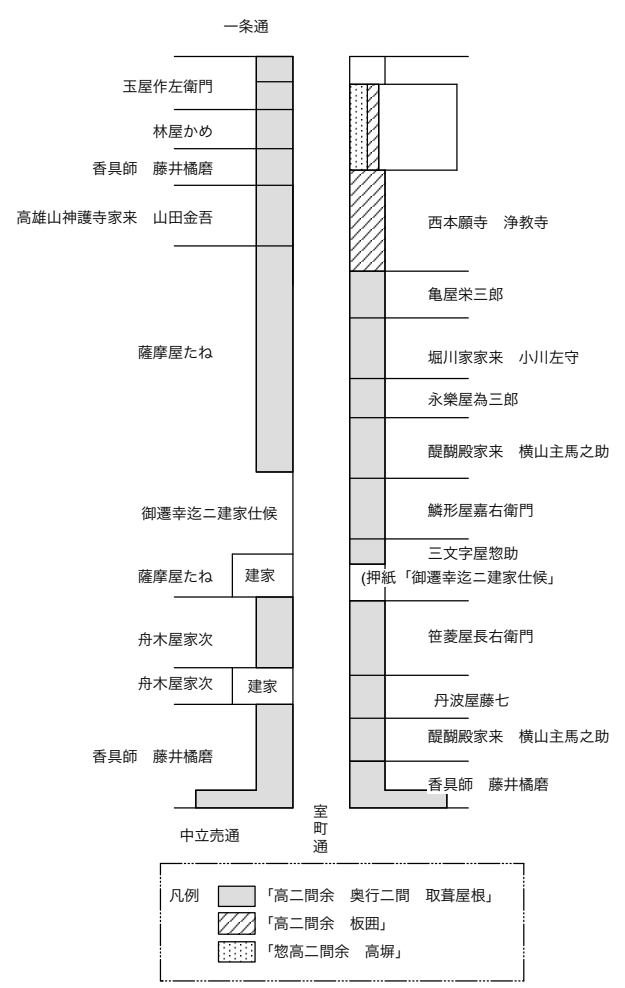

図 2 安政度遷幸道筋における仮設・板囲の事例 (典拠『遷幸御用留』(内閣文庫所蔵)
もある天皇

が見る際に

「御目障」

とされる内

容も解明し

ておかなけ

ればならな

いが、史料

からは明ら

かではない。

ただし、

拙稿で指摘

したように、

近世の天皇

は、近親者

の死去に伴

って穢れと

なる場合な

どを除き、

内侍所での

祭祀や神事

を担うため
の神聖性や清浄性を必要とされていた点は注意しておきたい22)。例 えば、【史料 1】下線部(1)で、寺町通では「御見越」の程が計りがた いとする。寺町通沿いには寺院が多い。高塀があるとはいえ、寺院 にある穢に関連するものが存在する可能性がある。墓地などが見え てしまうような事態は、避けなければならなかったのであろう。

また、近世中期には、東山天皇は上御霊社の風流を禁裏御所から 見ていた。しかし、その風流の築地之内一の侵入が「不吉」である という理由で、禁裏御所からの上覧は中止される吕。このように、 天皇や朝廷の存在に影響が想定されるようなものは、天皇の視界や 周囲から排除される。

したがって、天皇が町中を上覧する遷幸という朝儀時には、清浄 たるべく天皇の存在を安全に確保寸るに不都合のある要素等が取り 除かれた空間が都市のなかに創出されていたといえよう。

\section{3 遷幸の目的と背景}

最後に、安政度内裏遷幸の特性を明らかにするため、遷幸を実施 する朝廷側の意図、ならびにそれを受け入れる町や町人らの対応を 考察しておきたい。

\section{3-1 朝廷側の遷幸の目的}

公家や武家の記録において、内裏一の遷幸は「御行粧」と表記さ れる場合がある ${ }^{24)}$ 。行粧とは、旅や外出のよそおい(威儀をととのえ ること)を示す ${ }^{25)}$ 。天皇が遷幸するためには、その威儀を整え、見せ るための演出が必要であったことが認識されており、このような表 現が用いられていたのであろう。実際、禁裏御所の正式な門である 南門 (建礼門) ${ }^{26)}$ を通過する点や天皇の乗物として八葉御車ではなく 鳳輦が使用された点 ${ }^{27)}$ などは、正統かつ優位的な天皇の存在を示す ための対応であったと評価できる。

さらに、安政度の場合、幕府が内裏造営に対して身元宜しく裕福 とされた町人から献金を求めた点は留意しておきたい28)。前掲牧論 文に付される献金者一覽を分析すると、遷幸の道筋に居住地があっ たものも少なくないことが分かる。したがって、朝廷側・幕府側と もに献金した町人に対しての新造内裏への遷幸の披露を意図してい た可能性は否定できない。

以上から、朝廷側は天皇の威儀、つまり正式な内裏に遷幸すべき 正統かつ優越的な天皇の存在を町にむけて披露することを目的のひ とつとしていたと考えられる。

\section{3-2＼cjkstart町側の対応の背景}

一方、町側に目を向けると、前述のように様々な規制やしつらえ を求められる一方で、利点もあった。

そのひとつが、拝見である。前述のとおり、遷幸当日だけでなく、 その前日から多くの見物人が集まっていた。遷幸前夜には道筋の各 家の前(家並)に行燈が置かれ、道筋約 50 町に少なくとも松明 1750 本が設置されていた ${ }^{29)}$ 。人々は華やかかつ荘厳な䨌囲気に包まれた 都市空間を楽しんでいたのであろう。

そのなかで、沿道の町家では张見場所の賃料を取る商売が成立し ていた。『蛸薬師町文書』所収の前掲「新内裏遷幸道筋につき蛸薬師 町諸事要用録」には、町触の写しが残る ${ }^{30)}$ 。ここでは、帱見の規制 などが記されるとともに ${ }^{31}$ 、「拝見場所賃料等取候族於有之者急度可 申付条、所之もの共へ心を付可申候」とある。拝見場所を借りた人々 にも拝見の規則を伝えることが言い渡されたものであるが、換言す 
れば、拝見の場所の賃料を取る事例があったことになる。

しかも、この拝見場所は既存の町家だけでない。

【史料 4 】『遷幸御用留』安政 2 年 9 月

一、御道筋之内室町丸太町上儿西側熟尾家仮館前江茂、同様御 差出有之侯儀与存候、且室町中立売東南角二長橋局下り屋敷尾 辻焼失跡江若仮建物二而茂被取建侯哉、又者囲二而茂補理候哉、 承知いたし度、尤囲被致候事二候八、御組之もの者不被差出儀 与存候得共、仮建物出来拝見被致候儀二候八、是又御組之者被 差出候儀与存候、且又三条通東洞院東入北側に量華院殿拝見有 之不見透様、夫々被取斗方其筋江御掛合候上、否被御申聞候様 八多し度存候、

前述した遷幸道筋沿いの仮設のなかには、拝見ができるような場所 もあったのであろう。かかる場所が賃料を取っていたかは定かでは ないが、いずれにせよ、遷幸は、町人が経済的な利益を得る機会と なっていた。

また、拝見については、沿道の町内でさらに詳細な申し合わせが あった。

【史料 5 】『永書』(三井文庫所蔵) 安政 2 年 11 月

御遷幸二付当町内家並二張紙之間左之通、

申合之事

一、御遷幸之節平伏可仕事

一、無言者勿論無礼無之候様相慎可申候事

「(註 押紙) 老人小児拝見庭所二おいて別而無礼無之様 相慎可申事

一、火之元別而入念可申事

一、庭先拝見中火鉢田葉粉盆無用之事

一、毛遷蒲団等之敷物無用

一、庭先二而弁当無用之事

一、禁酒之事

一、男女かむりもの無用

一、御当日前夜共高声者勿論無益之雑談并騒敷致間敷事

一、前夜方表二階上り申間敷事

一、拝見後町分 5 致沙汰候追追出之儀者無用之事

右之通急度相心得可申事

$$
\text { 十一月町役 }
$$

「高声」に加えて、弁当や酒やたばこが禁止されている点は興味深 い。前述の賃料との関連性は不明であるが、扯見時に飲食や遊興を 兼ねる慣例があったのであろう。

ただし、このような行動は、場所代といった一時的な経済利益や 遊興だけを目的としたものではない。特に、沿道の有力町人のなか には、重要な接待の機会として活用寸るものもあったと考えられる。

三井文庫所蔵「拝見頼来候諸家方人数」 ${ }^{32)}$ からは、遷幸の沿道に ある冷泉町等に屋敷を構えていた豪商の三井家に大勢の人々が帱見 を申し出ていたことがわかる。しかも、この史料には「加州御屋敷」 （加賀） 5 人、「鴻池善五郎様」 8 人、「松平伊豆守様」 $12 \cdot 3$ 人、「二 条様」31 人など、武家や上層町人の代表者氏名と拝見希望人数が記 されており、幕府や禁裏御用もつとめていた三井家と経済的・社会 的な交流があったと推測される人々が拝見を希望していたことが判 明する ${ }^{33)}$ 。他にも、所司代用人や久留米藩屋敷などの武家、大工な どの町人らも記されているが、この史料からだけでも、総勢 300 人
以上が三井家での拝見を依頼していたことがわかる。これに対して 三井家が受け入れた人数は明らかではないが、多くの来賓があった ことはまちがいないであろう。

そして、三井家では、遷幸当日は朝から清掃などをした後、あら かじめ家内で決められた役割のもと、万全の体制で遷幸拝見の客人 を迎え、飲食のもてなしを行った ${ }^{34)}$ 。

このように、朝廷や幕府からの要求を受容できるだけの社会的基 盤を持ちうる町や有力町人らにとっては、遷幸は単なる経済的負担 を伴う朝儀というだけではなく、自らが所属する社会的ネットワー クを確認・形成する重要な機会でもあった。

加えて、さらに身分の高い人を接客する場合には、迎える側にも 相応の対応が求められた。史料 4 】では門跡である暑華院が見物す るために「不透」の工夫が求められている。また、『蛸薬師町文書』 には「一、西本願寺様町内誉田屋仁兵衛方へ拝見御成二付、町内為 御御挨拶鶴齢被申銘酒壱斗卜頂戴仕候、」 ) ある。このように、身 分の高い人々のもてなしができるだけの経済力・社会力を保持した 町人にとっては、貴人を迎え入れることができること、つまり自ら の社会的地位の高さを他者に主張できる機会でもあったのである。

\section{おわりに}

安政度内裏遷幸は、遷幸時に必要とされる諸対応を迷惑としない 町が多いと評価された室町通を通行する経路が選択された。さらに、 この経路決定や沿道の景観整備で重視された要素に、「御見越」があ る。遷幸には天皇の上覧に適した景観が必要とされ、特に沿道の町 にはそれに準じた仮設の設置等が求められた。

そして、その空間を舞台に、朝廷側は、天皇の威儀、つまり鳳輦 に載って南門から内裏に入る正統かつ優位的な天皇の存在を主張し ようとした。

一方、町側では、この遷幸を負担として受け入れただけではない。 町人らは遷幸を沿道の町で拝見した。そのなかでも、沿道に居住す る有力町人らは、公家、武家、上層町人、門跡や門主などを拝見の ために家に招いた。彼らは、この遷幸を通して、社会的ネットワー クを確認・形成するとともに、社会的地位を主張しょうとしていた と考えられる。

なお、遷幸という祝祭・朝儀が円滑かつ盛大に実施できた背景に は、京都の町や町人の経済的・社会的な力があったことは強調して おきたい。しかも、経路決定における室町通沿いの町の評価からも うかがえるように、かかる町の力を幕府だけでなく朝廷側も把握・ 活用しょうとしていた点は、近世後期の京都の特徴ともいえよう。

最後に、今後の研究展望を記しておく。安政度内裏遷幸の場合、 天皇は本稿で指摘したような経路で内裏に還った。一方、遷幸と同 日には、桂皇居にあった内侍所 (神鏡) が新造内裏に移された。ただ し、この神鏡は、惣門の外に出ることなく、築地之内を通って内裏 に移った ${ }^{36)}$ 。つまり、天皇と、神聖な天皇の存在を象徵し清浄であ ることが厳密に求められた内侍所 ${ }^{37)}$ は、別の経路を使って内裏に還 る。この差異は、安政度内裏遷幸だけでなく、内侍所を中心とした 禁裏のありかたを考える上でも重要である ${ }^{38)}$ 。よって、次稿では、 内侍所渡御の意義を本稿で明らかにした遷幸の特徵を踏まえて考察 することで、祝祭ならびに朝儀空間としての近世京都の都市空間の 特性をさらに解明していく予定である。 
注

1) 藤田覚「天皇 変わるものと変わらないもの」(『思想』1049、2011 年 9 月)。

2) 京都の町人であった高木在中の日記『幕末維新京都町人日記 高木在中日記』 (内田九州男他編（清文堂出版、1989 年））には、遷幸前々日に「遷幸二付 内見也、御所大群衆之由」、前日には「早々 万町々自身番相勤、夜同断。御 通筋多人数二而大混雑也。」と記される。

3) 天皇の還幸や葬送の道筋やそのしつらえに着目した研究として、小沢朝江 「近世における内裹外郭門と築地之内について」（『日本建築学会計画系論 文集』554、2002 年 4 月) や丸山祐未他「近世京都における貴人通行時の街路 の準備行為について」(『日本建築学会大会学術講演梗概集 (東海)』、2012 年 9月）などがある。また、丸山俊明「武士を見下ろしてはいかなかったのか」 (『京都の町家と町なみ一何方を見申様に作る事、堅仕間敷事』、昭和堂、2007 年) は、遷幸や天皇葬送時の町家の様相に着目寸る。これらの研究は、いず れも主に町触を根拠としている。なお、町触は、『京都町触集成』第 1 巻-別 巻 2 (京都町触研究会編、岩波書店、1983-1989 年) に所収される。以下、 本稿においては、『京都町触集成』を『町触』と表記する。

4) 近世災害研究会編『立命館大学グローバルＣＯEプログラム 歴史都市を守 る「文化遺産防災学」推進拠点 平成 22 年度報告書『嘉永七年京都大火 - 安 政度内裏造営関係史料』』(2011 年 3 月)。

5) 近世都市京都における祝祭空間の特性については、拙稿「近世前期の上・下 御霊社祭礼行列と天皇一風流見物を中心に一」(『建築史学』61、2013 年 9 月) がある。これは、禁裏御所で実施された天皇の風流見物に着目し、禁裏御所 を中心とした祝祭空間の特性とその意義を考察したものである。

6) 安政度内裏造営については、藤岡通夫『京都御所』(中央公論美術出版、1987 年) や平井聖他『中井家文書の研究』(中央公論美術出版、1976 84 年) を参 照した。また、拙稿「寬政度内裏造営以降の内侍所仮殿の造営・下賜と神嘉 殿」(『日本建築学会計画系論文集』591、2005 年 5 月) でも安政度内裏 (内侍 所) 造営について言及している。

7) 本稿で用いる『脇坂安宅日記鈔』ならびに『伝奏口上留』は『立命館大学安 政度内裏造営報告書』の翻刻を参照したが、使用および引用に際しては筆者 が原本を確認した。また、安政度内裏遷幸の経緯については一部『立命館大 学安政度内裏造営報告書』でも言及されており本稿でも適宜参照したが、本 稿 (本章) は空間特性や経路決定に着目してその経緯を再度整理、分析するも ので、論旨・目的が異なる。

8）『脇坂安宅日記鈔』安政 2 年 4 月 29 日条。

9) 『脇坂安宅日記鈔』安政 2 年 5 月 11 日条。

10）『町触』第 7 巻、 120 頁。

11) 近世中期の天皇・女院の葬列に関して典拠とした史料は以下のとおり。宝 永 6 年（1709）に崩御した東山院の葬列については、『桂宮日記』(宮内庁書 陵部所藏）宝永 7 年 1 月 10 日条。享保 5 年 $(1720)$ の新承秋門院について は、『松尾相匡日記』享保 5 年 3 月 5 日条。享保 17 年の霊元院については、 「霊元院尊儀御凶事一会」(『霊元天皇実録』(ゆまに書房、2005 年) 所収)。

12)『禁裏執次詰所日記』安永 8 年 11 月 15 日条 (『後桃園天皇実録』(ゆまに 書房、2006 年）所収）参照。

13) 安永 8 年以降に行われた天皇・女院の葬列の経路に関して、典拠とした史 料は以下のとおり。天明 3 年 (1783) の盛化門院に関しては『野宮定業日記』 (宮内庁書陵部所蔵) 天明 3 年 11 月 13 日条。寛政 7 年（1795）の恭礼門院 ならびに文化 10 年 (1813) の後桜町院に関しては、『町触』第 7 巻 (364 頁) ならびに第 9 巻 (288 頁)。天保 11 年 $(1840)$ の光格天皇ならびに弘化 3 年 （1846）の仁孝天皇に関しては、『野宮定功日記』(宮内庁書陵部所蔵）天保 11 年 12 月 20 日条ならびに弘化 3 年 3 月 4 日条。

なお、近世の天皇葬送儀礼と葬列空間の特性については、別稿にてその詳 細を考察する予定である。

14) 同時期の武家・朝廷の経済的状況に関しては、前掲拙稿「寬政度内裹造営 以降の内侍所仮殿の造営・下賜と神嘉殿」でも言及寸るとおり、厳しかった。 ゆえに、安政度内裹遷幸においても、寬政度と同様に武家側や寺院側の経済 的な負担も勘案された可能性も高いと考える。

15）『蛸薬師町文書』「新内裏遷幸道筋につき諸入用留帳」ならびに『京都冷泉 町文書』「八○安政二年十二月 御遷幸諸入用書抜」(京都冷泉町文書研 究会編『京都冷泉町文書』第 6 巻、1998 年) から、図 2 に示した蛸薬師町で は銀 3 貫 343 多 7 分 6 厘、冷泉町では 3 貫 56 多 7 分 9 厘が町の入用であっ たことがわかる。また、両町ともに金銭借用の記録はない。ただし、冷泉町 の場合、同時に不用物が売り払われており、この臨時の入用を捻出するため の対応であった可能性が考えられる。

16) 遷幸の道筋は、『町触』第 12 巻（204 頁）などに示される。なお、鈴木栄樹 氏は、安政度遷幸の道筋決定の最大要因を八葉御車や鳳輦が通るための道幅
の確保の問題と指摘する（鈴木栄樹「嘉永七年京都大火と安政度内裏造営一 「脇坂安宅日記鈔」「禁裏炎焼一件」を中心に一」（前掲『立命館大学安政度 内裏造営報告書』))。しかし、鳳輦が通るために必要な道幅は三間程度とさ れる。築地之内や寺町通であれば、この道幅の確保はむしろ容易である。

17)ただし、この御手当銀の使途は不明である。

18）『京都の地名』(平凡社、1979 年) 参照。

19）この御請書と同じもの内容の文書が、冷泉町（位置は図 1 参照）に屋敷を 構えていた三井家にも残っている (『申合之事(御遷幸拝見二関スル申合) 他 一式』「御道筋修覆及掃除方達之請書控」(三井文庫所蔵) 。

20）註 3）参照。

21)これらの板囲等の高さは、【史料 3】に示される、沿道で御見越」の可能性 がある箇所で目障りな場所に据えられた板囲の高さと一致する。

22) 拙稿「天皇の葬送儀礼と近世都市京都」（『特別研究 [若手奨励] 4 都 市建築史的観点からみた中央と地方に関する研究』（日本建築学会、2010 年 3 月))参照。

23）前掲拙稿「近世前期の上・下御霊社祭礼行列と天皇一風流見物を中心に一」。 24) 安政度内裹遷幸時の「遷幸御行粧」「「御行粧」という表記は、前掲『遷幸 御用留』所収の安政 2 年 7 月 3 日条の浅野中務少輔の書付や『勢田章甫筆記』 安政 2 年 11 月 23 日条（前掲『孝明天皇紀』所収）などで確認できる。

25）『日本国語大辞典』(小学館)参照。

26）禁裏御所内の門の性格については、前掲小沢「近世における内裹外郭門と 築地之内について」のほか、前掲拙稿「近世前期の上・下御霊社祭礼行列と 天皇一風流見物を中心に一」でも指摘している。

27) 遷幸計画当初は、天皇の乗り物として八葉御車の使用が検討されていたが、 鳳替に変更された。この経緯については、前掲鈴木「嘉永七年京都大火と安 政度内裏造営一「脇坂安宅日記鈔」「禁暠炎焼一件」を中心に一」に詳しい。

28) 安政度内裏造営に関する京都の町人の献金の概要や特徴については、牧知 宏「安政度内裏造営における京都町人の献金について」（前掲『立命館大学 安政度内裏造営報告書』) に詳しい。

29）『安政二年遷幸内裏鸴書』(宮内庁書陵部所蔵)安政 2 年 11 月の「仮皇居南 殿代階下 5 新内裏南殿階下迄凡道法五拾町之積」から、松明の数が判明する。 1 町 1 人に 10 本ずつで臀のみであれば合計 3500 本、 1 町 1 人 5 本ずつで臀 と竹を混合すれば合計 1750 本、が計画されているが、本記録にはどちらが 実施されたか明記されていない。なお、平田職修の日記『職修日記』(宮内 庁書陵部所蔵)には松明の数として後者 (1750 本)が記されている。

30) 前掲『蛸薬師町文書』所収「新内裏遷幸道筋につき蛸薬師町諸事要用録」 の触の写しは、『町触』第 12 巻 (204 頁) と内容が一致する。

31) 前掲丸山俊明論文 (註 3) 参照)において、拝見の場となった町家の特徵が指 摘されている。

32)『申合之事(御遷幸拝見二関スル申合)他一式』(三井文庫所蔵)所収。

33) 三井家の動向については、三井文庫編『三井事業史』(三井文庫、一九八 年) や賀川隆行『近世三井経営史の研究』（吉川弘文館、一九八五年）に詳 しい。また、拙稿「近世京都の都市空間再生と禁裏御所普請一三井家と町一」 (『特別研究 [若手奨励] - 8 国際的・都市史的観点からみた都市再生論に 関する研究』(日本建築学会、2012 年 3 月) で、三井家の禁裏御所普請に関す る御用と新造内裹择見に言及している。

34 ) 前掲『申合之事(御遷幸拝見二関スル申合)他一式』による。家内の役割と して、「御屋敷方 新二階」、町内出役」のほか、台所での「餅焼方」、「諸 道具洗い役」などが記される。

$35)$ 前掲「新内裹遷幸道筋につき蛸薬師町諸事要用録」安政 2 年 11 月 22 日条。 36)「日時勘文御用記」(『孝明天皇紀』第二(有隣堂、1967 年) 所収)。 37) 近世の内侍所の性格については、前掲拙稿「天皇の葬送儀礼と近世都市京 都」を参照されたい。

38) 近世の内侍所の動向に関しては、筆者の一連の研究に詳しい(「近世内裹内 侍所仮殿下賜と上・下御霊社について」(『日本建築学会計画系論文集』575、 2004 年 1 月)、「近世禁董御所と都市社会一内侍所参詣を中心として」(『年報 都市史研究』15、2007 年 12 月)など)。

【附記】本稿は、日本建築学会都市史小委員会シンポジウム「都市と表象」 シリーズ「消費と生産」(平成 24 年 12 月開催) において「権威と消費一安政 度内裏遷幸と町」として発表した内容を、大幅に加筆・修正したものである また、本稿は、科学研究補助金 (基盤研究 (C) 課題番号 22560640、研究代表 者 岸泰子) による成果の一部である。

(2013年 6 月 10 日原稿受理，2013年 9 月24日採用決定） 